Article

\title{
Seasonal Performance Evaluation of Pavement Base Using Recycled Materials
}

\author{
Yang Zhang ${ }^{1}{ }^{\mathbb{D}}$, Bora Cetin ${ }^{2, *}$ and Tuncer B. Edil ${ }^{3}$ \\ 1 School of Transportation, Southeast University, Nanjing 211189, China; yang-zhang@seu.edu.cn \\ 2 Department of Civil and Environmental Engineering, Michigan State University, East Lansing, MI 48824, USA \\ 3 Civil and Environmental Engineering Department, University of Wisconsin-Madison, Madison, \\ WI 53706, USA; tbedil@wisc.edu \\ * Correspondence: cetinbor@msu.edu
}

check for

updates

Citation: Zhang, Y.; Cetin, B.; Edil,

T.B. Seasonal Performance Evaluation

of Pavement Base Using Recycled

Materials. Sustainability 2021, 13,

12714. https://doi.org/10.3390/

su132212714

Academic Editor: Don Cameron

Received: 2 October 2021

Accepted: 12 November 2021

Published: 17 November 2021

Publisher's Note: MDPI stays neutral with regard to jurisdictional claims in published maps and institutional affiliations.

Copyright: (c) 2021 by the authors. Licensee MDPI, Basel, Switzerland. This article is an open access article distributed under the terms and conditions of the Creative Commons Attribution (CC BY) license (https:/ / creativecommons.org/licenses/by/ $4.0 /)$.

\begin{abstract}
Using recycled pavement materials to construct new pavement base is currently an important construction strategy bringing improved sustainability. This study investigates the long-term performance of pavement bases constructed with recycled concrete aggregate (RCA), reclaimed asphalt pavement (RAP), and blends with natural aggregates in a seasonal frost region. The stabilization effect of fly ash on RAP was studied as well. In situ falling weight deflectometer (FWD) tests were routinely conducted to provide seasonal deflection data, which were used to back-calculate the layer modulus. Seasonal changes in the base layer modulus along with the pavement ride quality were monitored. One of the two lanes at the test sections was consistently subjected to traffic loading, whereas the other one was not. Findings from this field research indicated that after undergoing over 8 years of naturally seasonal freeze-thaw conditions, 100\% RCA, 50\% RCA, plus 50\% natural aggregates, and $100 \%$ RAP, presented improved performance over $100 \%$ natural aggregates. However, $50 \%$ RAP blended with $50 \%$ natural aggregates performed comparably to natural aggregates only, and fly ash did not provide considerable improvement on the long-term performance of $50 \%$ RAP plus 50\% natural aggregate base. Seasonal climatic variations turned out to affect pavement performance more critically than traffic loading.
\end{abstract}

Keywords: pavement base; seasonal freezing; falling weight deflectometer; back-calculated modulus; recycled concrete aggregate; reclaimed asphalt pavement

\section{Introduction}

\subsection{General Background}

Making engineering materials more sustainable has become increasingly attractive over the last few years, not only to diminish project costs but also to minimize the impact on the environment $[1,2]$. Towards this goal, pavement engineers and researchers have spent substantial effort to explore the feasibility and suitability of recycling waste materials in new pavement structures, including glass [3,4], asphalt pavement [5], recycled concrete [6], fly ash [7], clay bricks [8], steel slag [9], palm oil fuel ash [10], sulfur [11], and waxes [12], as well as all kinds of polymers, such as polyethylene terephthalate (PET) [13], high-density polyethylene (HDPE) [14], low-density polyethylene (LDPE) [15], polystyrene (PS) [16], polyurethane (PU) [17], polypropylene (PP) [18], acrylonitrile butadiene styrene (ABS) [19], polyvinyl chloride (PVC) [20], and others. Among those innovative applications, using recycled pavement materials for new pavement base or subbase layers is the most universal one gaining interest in transportation earthworks.

Looking at relevant literature in recent years shows that recycled pavement materials, usually focusing on recycled concrete aggregate (RCA) and reclaimed asphalt pavement (RAP), have been well studied in the laboratory [21,22]. These are different than the fulldepth reclamation technique, which recycles composite pavement materials from surface to base and subbase (and may even include some content from the subgrade). RCA and RAP 
usually consist of recycled materials from the pavement surface only [23,24]. Furthermore, hot recycling and cold recycling are two commonly used methods for constructing pavement layers using recycled pavement materials. The main difference between cold and hot recycling techniques refers to whether the existing bitumen in recycled materials is heated to restore its viscosity prior to compacting [23,24]. Overall, the investigated topics of these studies on recycled pavement materials are categorized into three aspects: (i) characterizing the mechanical properties, such the strength and stiffness that may represent the capacity to bear traffic loading $[25,26]$; (ii) evaluating their durability to freeze-thaw and wet-dry cycles [27,28]; and (iii) environmental impacts such as the leaching of metals and high alkalinity and $\mathrm{pH}[29,30]$. Generally, findings from these laboratory investigations demonstrated that recycled pavement materials are able to provide comparable performance to normally used aggregate base materials, such as crushed limestone and granite [31-36]. The use of recycled materials in pavement construction is a beneficial activity in terms of life cycle assessment, i.e., it reduces energy consumption and greenhouse gas emissions in material production associated with natural materials and in terms of life cycle costs [29]. Per data from NASA, globally there are 55 million $\mathrm{km}^{2}$ of seasonal frost regions that possess $55 \%$ of the total continent area [37]. That means over half of the pavements in this world are subjected to seasonal freeze-thaw cycles, which may significantly weaken pavement structures in the long term. However, field studies on pavement base using recycled pavement materials, especially with respect to the long-term performance, are exceptionally limited. To take into account all the above factors, it is necessary to assess the long-term performance of pavement base using recycled materials in seasonally freezing regions.

There are numerous studies to investigate laboratory performance and the suitability of using recycled pavement materials as pavement foundations, especially on their mechanical properties and freeze-thaw actions [31,32]. In summary, these laboratory findings indicated that seasonal freeze-thaw cycles had a significant effect on weakening the mechanical properties of pavement foundation materials, including unstabilized and stabilized recycled pavement materials. On the other hand, there are fewer field studies studying the recycled pavement materials as pavement foundations under seasonal freeze-thaw cycles [28,38]. The field test results matched the laboratory freeze-thaw test results $[30,38]$.

Falling weight deflectometers (FWDs) have been widely used to evaluate the pavement performance in terms of stiffness, and FWD deflection data are always representative of the composite pavement performance $[39,40]$. With the intent to rate subsurface conditions, it is necessary to come up with approaches assessing parameters that are able to represent base, subbase, and subgrade properties. MODULUS, which was developed at the Texas Transportation Institute [41], is a widely used computer program for back-calculating layer moduli. To study the effect of seasonal variations on layer mechanical properties, there are two important factors that need to be considered during back-calculation, which are asphalt temperature during testing and subsurface moisture conditions. Both may affect back-calculation results, as adjustments are needed to account for their influences on the modulus $[42,43]$.

\subsection{Scope and Objectives}

The purpose of this study was to evaluate the seasonal long-term performance of pavement bases using various recycled pavement materials. The detailed objectives of this study to achieve this goal are listed below.

- To conduct in situ performance tests during seasons covering a long time span on test sections to evaluate the seasonal pavement performance changes;

- To back-calculate the layer modulus of test sections constructed with different recycled pavement materials, including RCA, RAP, and blends, with normally used aggregates in comparison with the conventional aggregate itself to monitor seasonal layer modulus changes; 
- To evaluate the effect of fly ash stabilization on recycled pavement materials in terms of resisting weakening from seasonal freeze-thaw cycles;

- To compare the effects from seasonal variations and traffic loading on long-term pavement performance.

\section{Materials and Pavement Layouts}

\subsection{Materials}

In this study, a total of seven test sections (numbered Section 1 to Section 7) were built with various base materials, including RCA, cold-recycled RAP from a partial depth reclamation work, commonly used natural aggregates that are classified as MnDOT (Minnesota Department of Transportation) Class 3 through Class 6, and blended aggregates with recycled and natural materials. An additional section (Section 7) was treated with $14 \%$ fly ash to evaluate the stabilization improvement on aggregate base. The aggregate index properties for all sections are summarized in Table 1. In accordance with the Unified Soil Classification System (USCS), most of the studied aggregates were classified as SP (poorly graded sand), except for Section 1 and Section 4, which were classified as SW (wellgraded sand) and GW-GM (well-graded gravel with silt). It was noted that the aggregate in Section 4, i.e., $100 \%$ MnDOT Class 5, apparently had more fine content than the other six aggregates.

Table 1. Summary of index properties of the aggregates in this study.

\begin{tabular}{|c|c|c|c|c|c|c|c|}
\hline Section No. & 1 & 2 & 3 & 4 & 5 & 6 & 7 \\
\hline \multirow{2}{*}{ Material } & $100 \%$ & $50 \%$ RCA $+50 \%$ & $100 \%$ & $100 \% \mathrm{MnDOT}$ & $50 \%$ RAP $+50 \%$ & 100\% MnDOT & $50 \%$ RAP $+50 \%$ MnDOT \\
\hline & RCA & MnDOT Class 5 & RAP & Class 5 & MnDOT Class 4 & Class 6 & Class $3+14 \%$ Fly Ash \\
\hline USCS Symbol & SW & $\mathrm{SP}$ & SP & GW-GM & $\mathrm{SP}$ & SP & $\mathrm{SP}$ \\
\hline AASHTO Symbol & A-1-a & $A-1-b$ & A-1-a & A-1-b & A-1-a & A-1-a & A-1-a \\
\hline Gravel Content (\%) & 31.8 & 32.7 & 26.3 & 22.9 & 28.4 & 31.5 & 35.1 \\
\hline Sand Content (\%) & 64.9 & 63.8 & 71.2 & 67.6 & 69.1 & 62.4 & 60.4 \\
\hline Fine Content (\%) & 3.3 & 3.4 & 2.5 & 9.5 & 2.5 & 6.1 & 4.5 \\
\hline
\end{tabular}

\subsection{Pavement Layout}

Because it was a collaborative project, the pavement layouts of the seven test sections can be generally classified into two categories (see Figures 1 and 2), with a length of 500 feet $(152.4 \mathrm{~m})$ for each test cell. For Section 1 to Section 4, the pavements consisted of a $127 \mathrm{~mm}$ surface layer of warm mix asphalt (WMA), a $305 \mathrm{~mm}$ base layer, and a $483 \mathrm{~mm}$ granular subbase layer. It was noted that the subbase layers in fact were formed with a $305 \mathrm{~mm}$ thick of MnDOT Class 3 aggregate and a $178 \mathrm{~mm}$ thick of selected granular materials. However, these two layers were treated as a combined subbase layer due to the emphasis of this study on the base layer and the limitations of the computer program applied in this study. In MODULUS, the base layers were assessed as an entirety above subbase and subgrade. Regardless of the classification of the layers beneath base, the calculated modulus of the base was not affected theoretically. 
Section 1

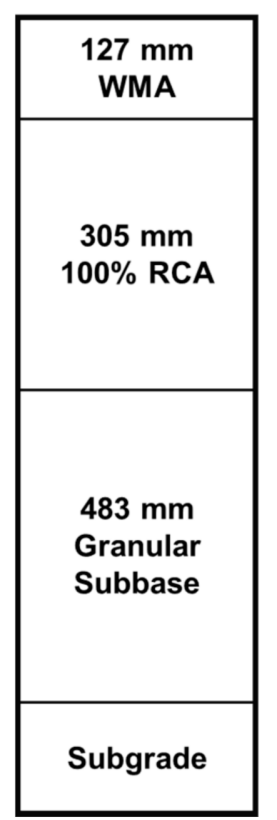

Section 2

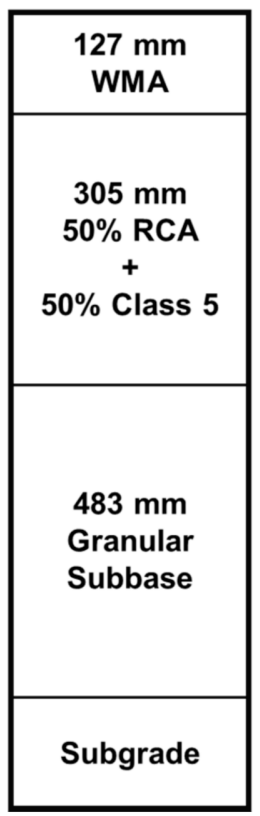

Section 3

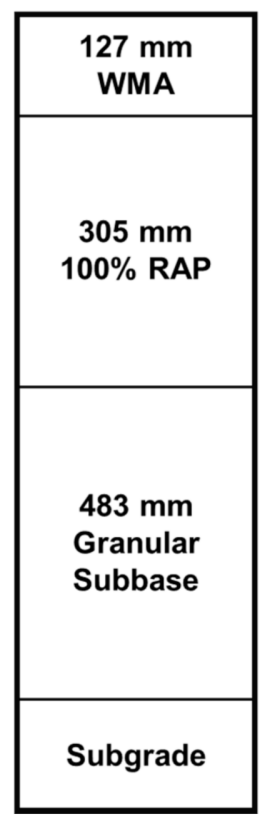

Section 4

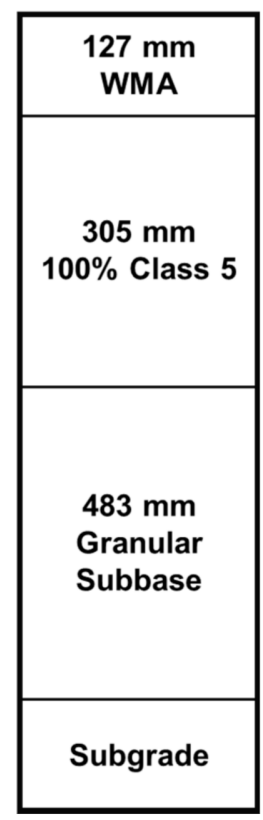

Figure 1. Pavement layouts of Sections 1-4 (not to scale).

Section 5

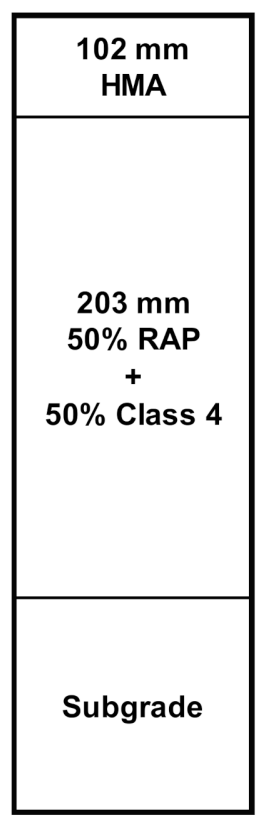

Section 6

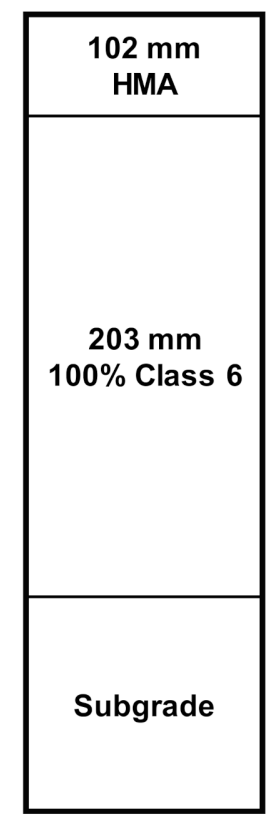

Section 7

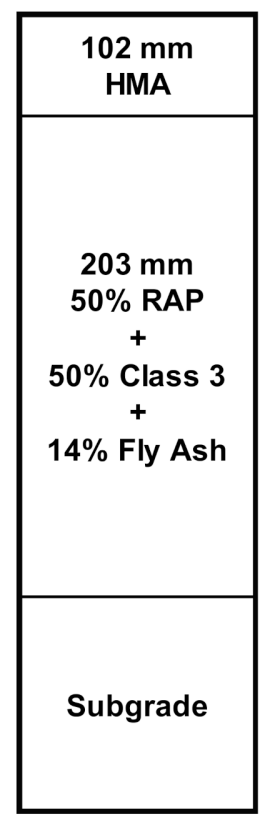

Figure 2. Pavement layouts of Sections 5-7 (not to scale).

\section{Methods}

The surface deflections of all test sections were measured via in situ FWD tests. In this research, a Dynatest model 1000 FWD was used, which has configurations including a $40 \mathrm{kN}$ applied load, a $300 \mathrm{~mm}$-diameter plate, and deflection sensors instrumented at $0,0.30,0.61,0.91,1.22$, and $1.52 \mathrm{~m}$ from the center of the load plate (Figure 3 ). The FWD tests were performed at every $30 \mathrm{~m}$ in each test section either monthly or seasonally. The FWD tests were conducted with the collection of the data from spring 2009 to fall 2017 for Sections 1-4 and from spring 2008 to fall 2017 for Sections 5-7. The measured deflections were used to back-calculate the elastic modulus of the aggregate base layers (referred to as 
$\left.E_{F W D}\right)$ using the MODULUS 6.0 software program developed at the Texas Transportation Institute [41]. A Poisson ratio of 0.4 was the input for the subgrade and 0.35 was the input for the asphalt surface layer, aggregate base layer, and subbase layer, in accordance with the suggested values specified in Huang [44]. The deflection measurements collected from the five longitudinal locations in each test section were used for the back-calculations to obtain the elastic moduli, and therefore the averaged elastic modulus from five locations was used and reported for each test section. FWD tests at each pavement section were conducted to measure deflections at transverse spacings corresponding to the mid-lane $(\mathrm{M})$ and outer-wheel $(\mathrm{O})$ paths for both the driving $(\mathrm{D})$ and passing $(\mathrm{P})$ lanes. For each individual test, three drops were carried out.

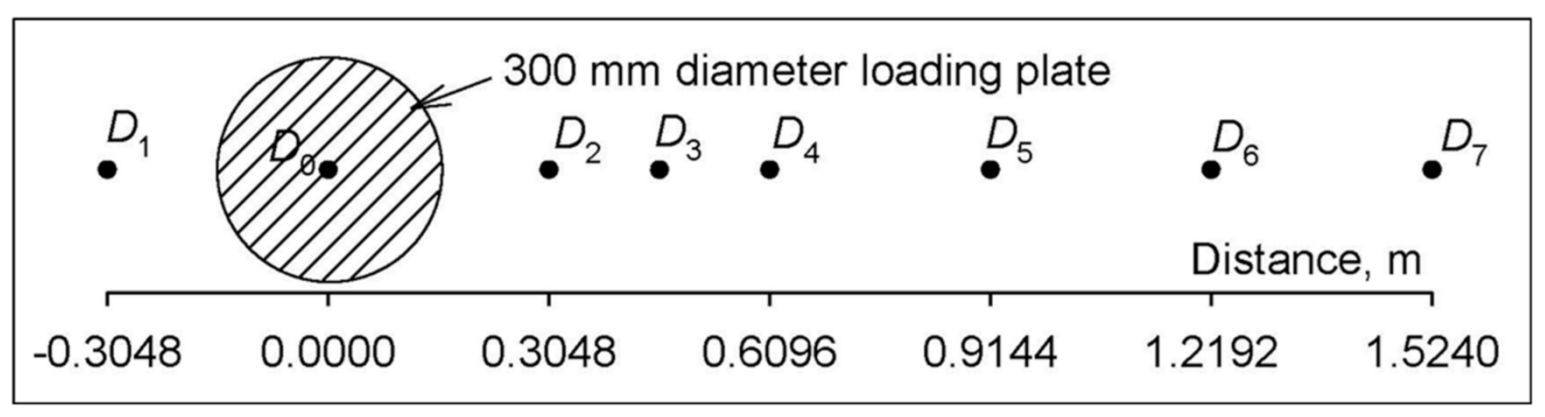

Figure 3. Sensor layout (plan view) of the FWD equipment employed in this study.

Rutting and the international roughness index (IRI) were monitored for Sections 1-4 until 2015. A lightweight profiler was utilized to collect IRI readings at a high frequency. An advanced laser profile system (ALPS) was utilized to collect rutting readings every $15.24 \mathrm{~m}$ with a $3.81 \mathrm{~m}$-long beam, so rutting was measured at 9 spots at each test section. Additionally, temperature sensors were instrumented into PVC pipes that were vertically embedded in each pavement section. Sensors were placed with certain spacing to ensure temperature at each layer was monitored. This study focused on the surface temperature and the base layer temperature near the layer bottom in order to assess the thermal performance of the tested base materials. The method utilized to calculate the number of freeze-thaw cycles was given by Rosa et al. [2], and is based on determined freezing temperatures for various geomaterials.

\section{Results and Discussion}

During this study, the passing lane was closed to traffic intentionally due to the experimental design. As common sense to pavement engineers and researchers, pavements keep deteriorating because of two factors: traffic loading and climate impact. Although differences in traffic can be easily assessed quantitatively, the effect of climatic variation is always difficult to investigate. Instead of employing the traditional method of direct investigation, this project attempted to study seasonal climate change in a roundabout way. Therefore, the passing lane was not subjected to traffic loading at all in order to isolate the effect of climate variations on pavement performance.

The deflection data and pavement surface temperature data collected from FWD testing were analyzed to back-calculate layer modulus with surface temperature adjustments. The elastic moduli of the base layers, $\mathrm{E}_{\mathrm{FWD}}$, were plotted versus seasonal testing time for the following testing locations: the mid-lane of the driving lane (D-M), the outer wheel path of the driving lane (D-O), the mid-lane of the passing lane (P-M), and the outer wheel path of the passing lane (P-O). The equivalent single axle load (ESAL) for the test sections was 20,000 per year based on the standard axle load, calculated based on an AADT of 1100 and an AADT for heavy vehicles of 275. Figures 4-10 present the $\mathrm{E}_{\mathrm{FWD}}$ results for Sections 1 to 7 , reflecting the different types of base materials. Note that the dates listed at the top of each individual plot do not indicate the testing days but rather the scale and intervals 
of the axes. FWD tests were conducted either monthly or seasonally to capture pavement performance at each season.
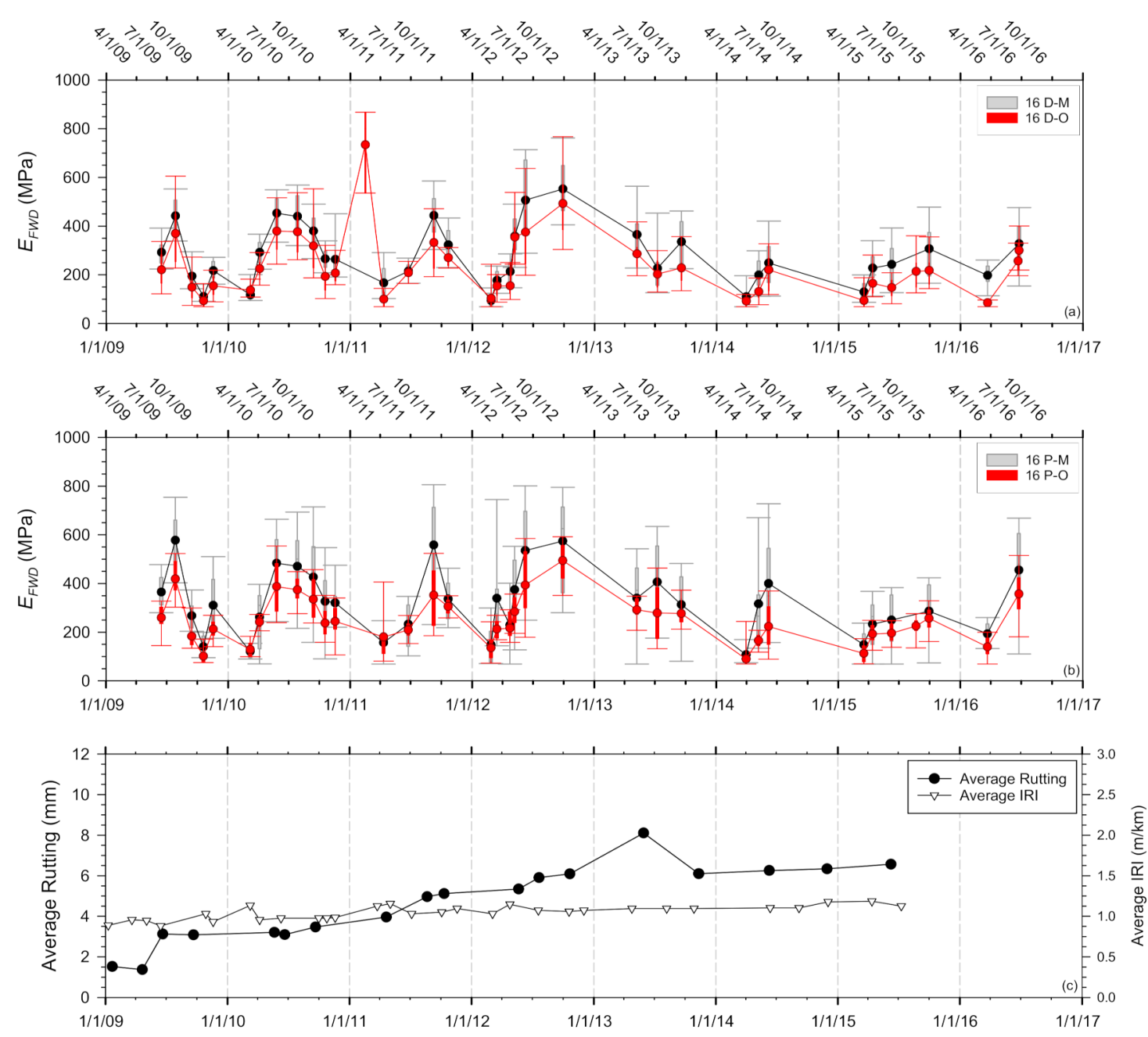

Figure 4. Seasonal variations in (a) driving lane $\mathrm{E}_{\mathrm{FWD}}$, (b) passing lane $\mathrm{E}_{\mathrm{FWD}}$, and (c) surface rutting depth of Cell 16 base- $-100 \%$ RCA (Section 1).

For Sections 1 to 4 , the average rutting depth and IRI values at each test season were plotted as showed in part (c) in Figures 4-7. In general, both the rutting depth measurements and IRI values increased gradually with time, as expected and reported in the literature [45-47]. Comparing the slopes of both curves, the changes in IRI values were lower than the rutting depth. All IRI values remained at about $1.0 \mathrm{~m} / \mathrm{km}$ for all sections during the entire monitoring period. In contrast to IRI, the rutting depth measurements increased from $<1.5 \mathrm{~mm}$ to up to $10.0 \mathrm{~mm}$ after 6.5 years of monitoring. However, the results did not indicate any significant differences between the types of base aggregates in maintaining low IRI and controlling rutting development. Section 3, constructed with $100 \%$ RAP base, eventually showed slightly higher rutting depth than other sections.

Seasonal variations in $\mathrm{E}_{\mathrm{FWD}}$ were revealed at all sections. Overall, for each calendar year, the highest $\mathrm{E}_{\mathrm{FWD}}$ values were obtained from FWD tests conducted in summer, and the lowest $\mathrm{E}_{\mathrm{FWD}}$ values were in spring or fall. This led to a reverse "V" shape for each $\mathrm{E}_{\mathrm{FWD}}$ year curve. The lower modulus in spring was likely attributed to spring thawing, where thawed water was trapped in base layers, which weakened the layer stiffness. As the season moved to summer, the modulus recovered to a higher value until early fall. In late fall and early winter at the project site, short freeze-thaw cycles started taking place, 
which possibly resulted in the decreases in $\mathrm{E}_{\mathrm{FWD}}$. If the modulus measured at spring was apparently higher than other seasons, for example the $\mathrm{E}_{\mathrm{FWD}}$ of the D-O of Section 1 in early 2011, it indicates that the full spring thaw was not captured and that the base was probably still frozen when conducting the FWD tests. Frozen base showed higher stiffness than it in other seasons.
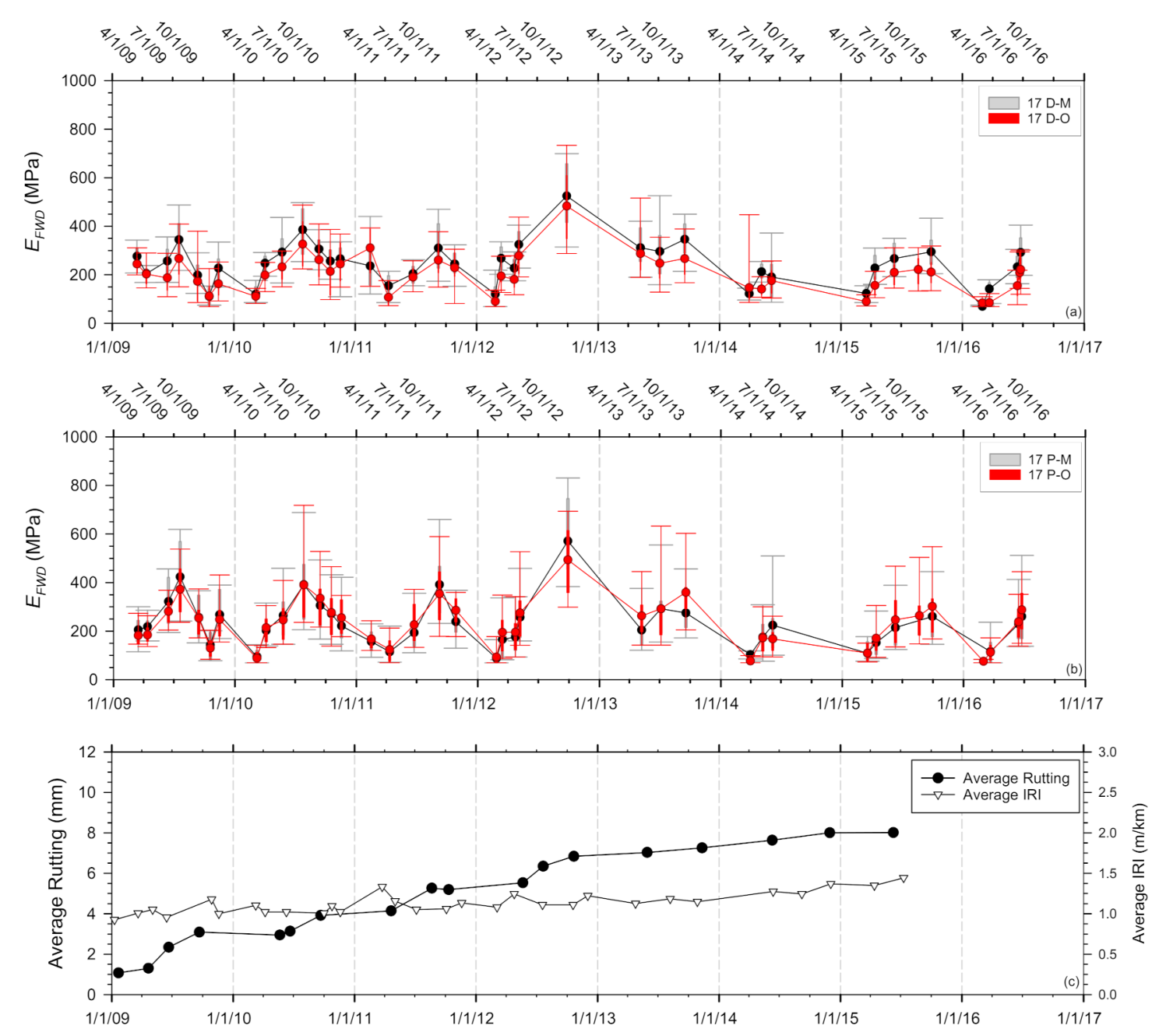

Figure 5. Seasonal variations in (a) driving lane $\mathrm{E}_{\mathrm{FWD}}$, (b) passing lane $\mathrm{E}_{\mathrm{FWD}}$, and (c) surface rutting depth of Cell 17 base- $-50 \%$ RCA $+50 \%$ Class 5 (Section 2).

Overall, the $\mathrm{E}_{\mathrm{FWD}}$ at the mid-lane was commensurable with that at the outer wheel path, especially for the passing lanes. Because the passing lane was not subjected to traffic, this finding is reasonable, as the climatic effect on the pavements should not have differed between testing locations. For several sections, the mid-lane average $\mathrm{E}_{\mathrm{FWD}}$ was slightly higher than the outer wheel-path values, especially for the driving lanes, which was likely caused by traffic loading. Similar to the mid-lane versus the outer wheel path, the overall results did not exhibit a significant difference between the driving lane and passing lane, which means traffic loading did not affect base modulus variation as critically as seasonal variations.

Comparing the results among the sections presented interesting findings. Sections with RCA, i.e., Sections 1 and 2, demonstrated wider ranges of $\mathrm{E}_{\mathrm{FWD}}$ from below $100 \mathrm{MPa}$ up to $800 \mathrm{MPa}$, whereas the other six sections showed a relatively constant $E_{F W D}$. For the $100 \%$ RAP section, the modulus varied widely in the driving lane in the beginning years and then fell to a constant level around $300 \mathrm{MPa}$, but the passing lane values were within a smaller range of 200-400 MPa throughout. 

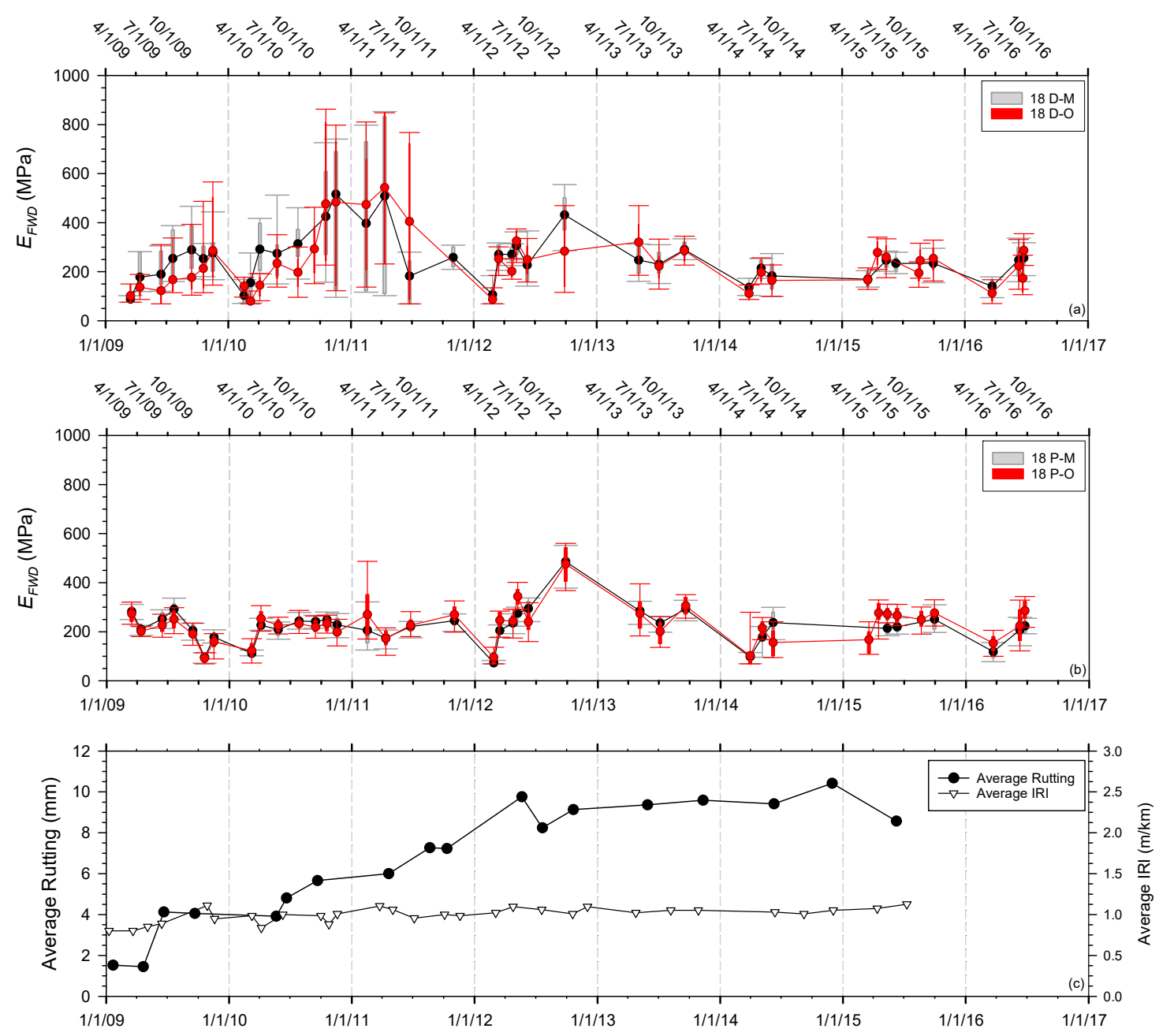

Figure 6. Seasonal variations in (a) driving lane $\mathrm{E}_{\mathrm{FWD}}$, (b) passing lane $\mathrm{E}_{\mathrm{FWD}}$, and (c) surface rutting depth of Cell 18 base-100\% RAP (Section 3).

Referring to Figures 7 and 9, pure natural aggregates did not show significant differences in $\mathrm{E}_{\mathrm{FWD}}$ even though MnDOT Class 5 had a different gradation than Class 6. The $\mathrm{E}_{\mathrm{FWD}}$ of Class 5 base was around $100 \mathrm{MPa}$, and $\mathrm{E}_{\mathrm{FWD}}$ of Class 6 base ranged from 70 to $120 \mathrm{MPa}$. The higher fine content of Class 5 might have contributed to this finding.

The effect of fly ash stabilization was assessed by comparing the results from Sections 5 and 7 (Figure 10). Section 5, where the base was constructed with 50\% RAP plus 50\% natural aggregates, showed an $\mathrm{E}_{\mathrm{FWD}}$ of less than $85 \mathrm{MPa}$ in most seasons and up to $110 \mathrm{MPa}$ for a few seasons. After adding $14 \%$ fly ash, the $\mathrm{E}_{\mathrm{FWD}}$ was constantly controlled at about $100 \mathrm{MPa}$, either in spring or other seasons. This indicates that fly ash did not significantly improve the stiffness of the $50 \%$ RAP plus $50 \%$ natural aggregate base layer, but possibly improved its resistance to seasonal variations.

In addition, two figures were plotted based on the pavement temperature data. As shown in Figure 11a, the surface temperature and the temperature measured within the base layers were compared. Over the monitored years, the highest and lowest surface temperatures were recorded as 59 and $-23{ }^{\circ} \mathrm{C}$, respectively. However, the base temperatures shown in Figure 11a (measured at similar depths) showed explicit differences in some seasons, indicating the varying thermal performance of the constructed base materials. Possible influencing factors include varying water contents, void ratios, chemical components, fine content, etc. 

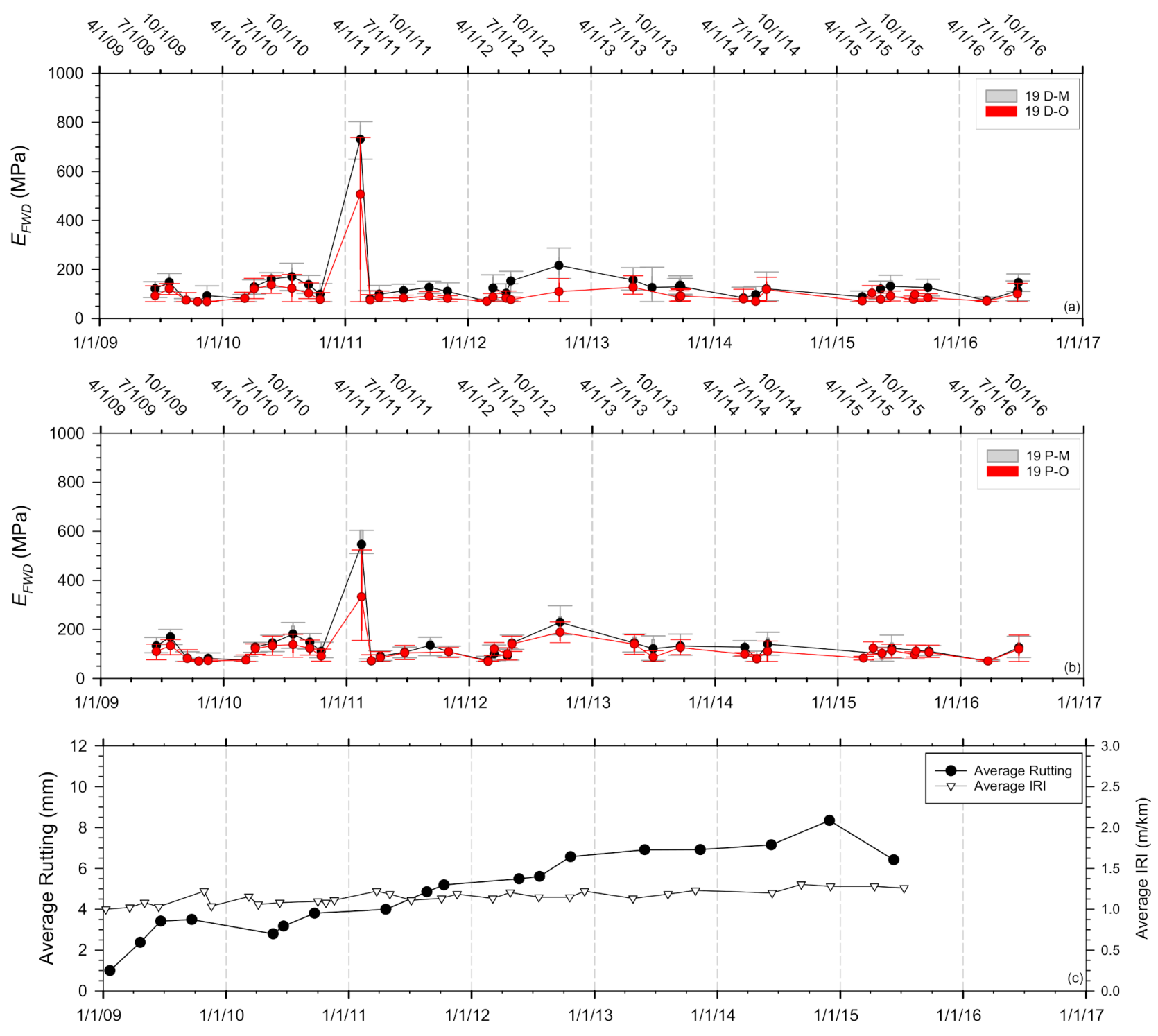

Figure 7. Seasonal variations in (a) driving lane $\mathrm{E}_{\mathrm{FWD}}$, (b) passing lane $\mathrm{E}_{\mathrm{FWD}}$, and (c) surface rutting depth of Cell 19 base- $100 \%$ Class 5 (Section 4 ).

Numerous freeze-thaw cycles were observed in the surface temperature data from each year, similar to the base measurements. However, as described, this study accounted for the determined geomaterial freezing temperatures as the boundary condition, i.e., for each type of base material, one freeze-thaw cycle was taken into account once the temperature decreased below and then increased above freezing. Via this approach, the number of freeze-thaw cycles in each base over the years until 2015 was calculated. The $E_{F W D}$ values representing base stiffness after a particular number of freeze-thaw cycles are shown in Figure 11b, indicating the effect of freeze-thaw cycles on the seasonal changes in the modulus. It was found that the representative base modulus for all seven sections either gradually decreased or showed no loss as the freeze-thaw cycles accumulated yearly. However, it is impossible to conclude which material stiffness was influenced the most by freeze-thaw cycles due to the difficulty in capturing the theoretically representative modulus. In other words, there may have been other moduli better reflecting the base stiffness after a certain number of freeze-thaw cycles. However, the time to conduct the FWD in this study may not have been adequate enough to represent that equilibrium condition. 

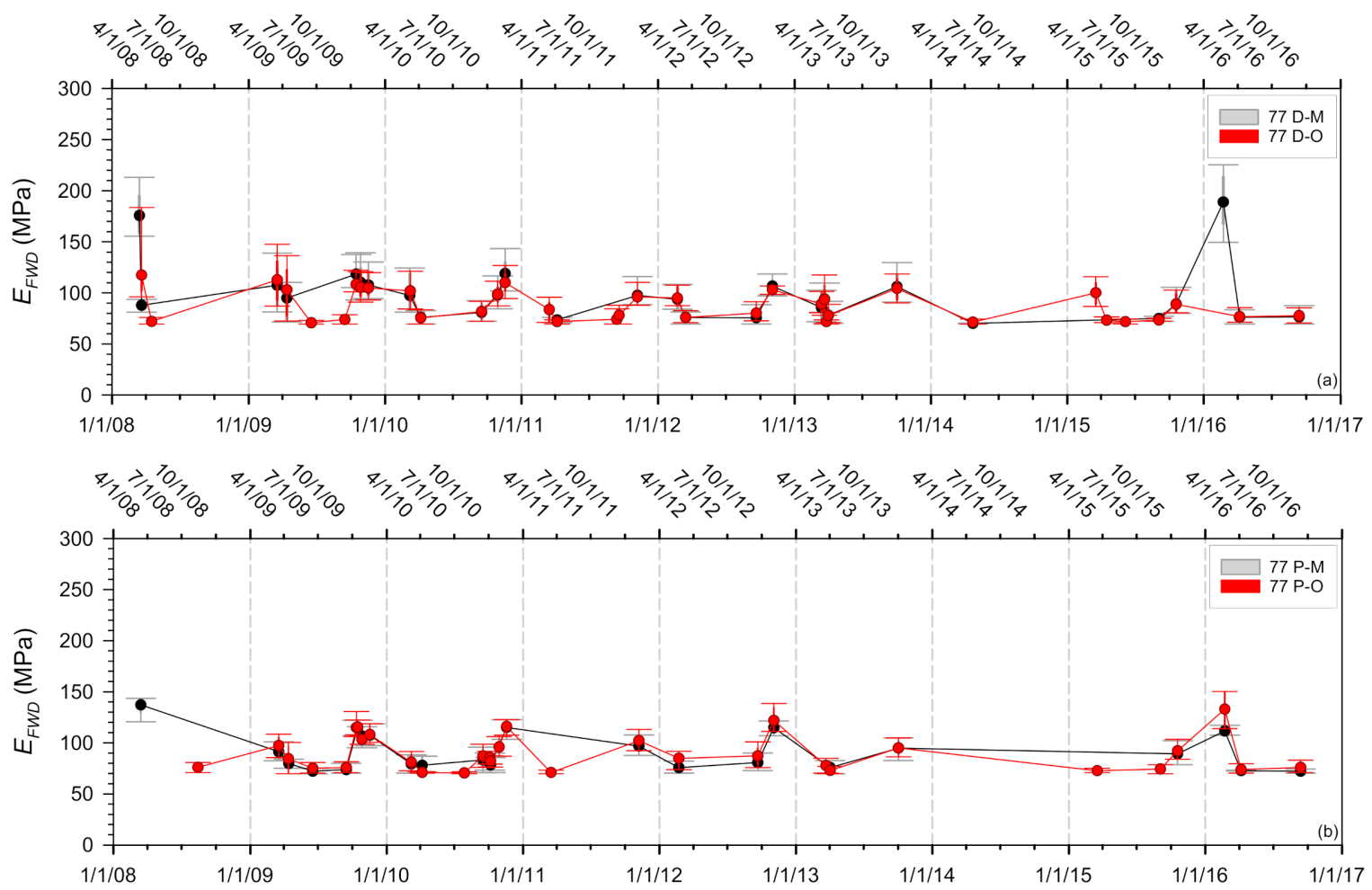

Figure 8. Seasonal variations in (a) driving lane $\mathrm{E}_{\mathrm{FWD}}$ and (b) passing lane $\mathrm{E}_{\mathrm{FWD}}$ of Cell 77 base- $50 \%$ RAP $+50 \% \mathrm{Class} 4$ (Section 5).
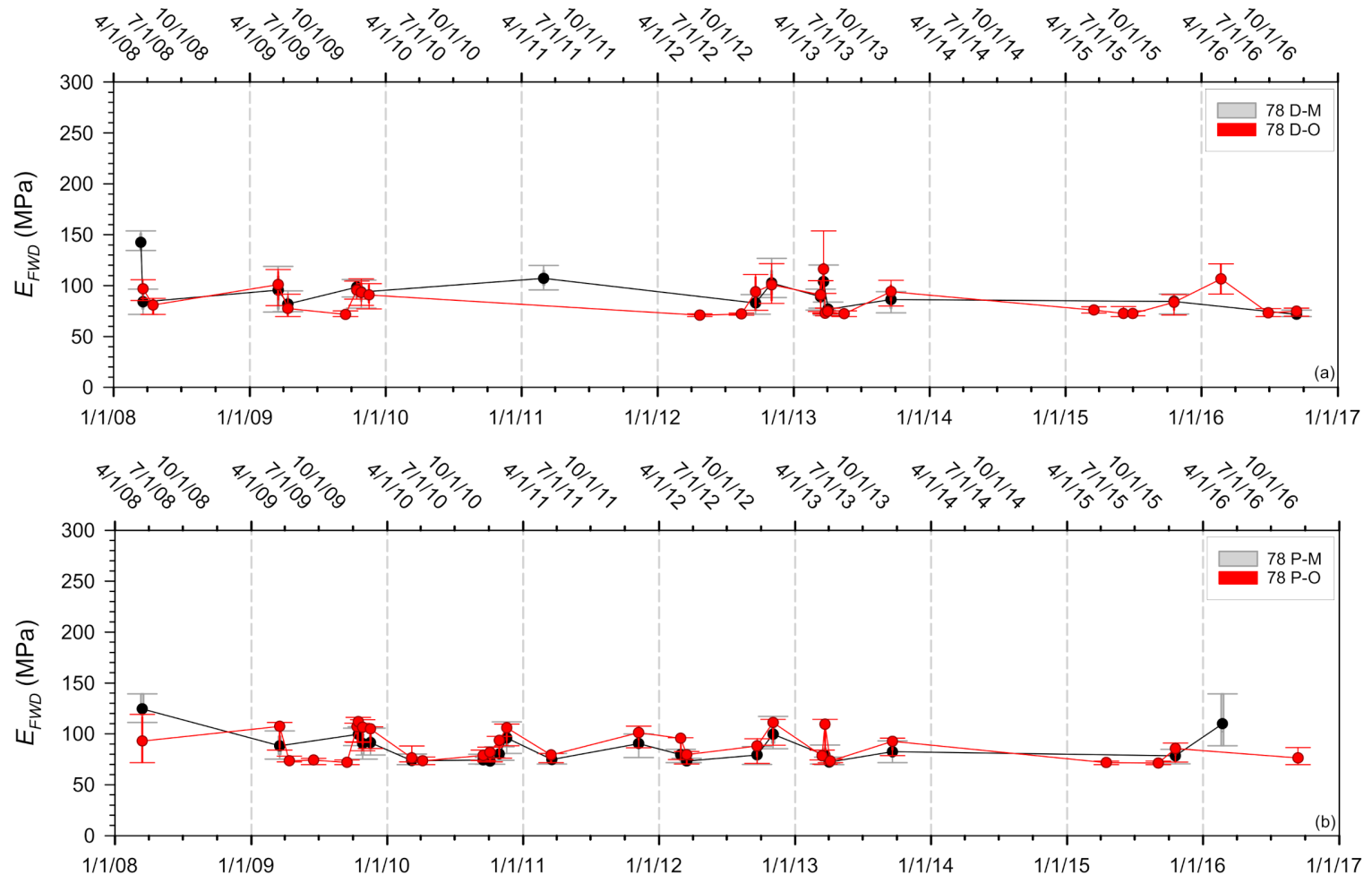

Figure 9. Seasonal variations in (a) driving lane $\mathrm{E}_{\mathrm{FWD}}$ and (b) passing lane $\mathrm{E}_{\mathrm{FWD}}$ of Cell 78 base-Class 6 (Section 6). 

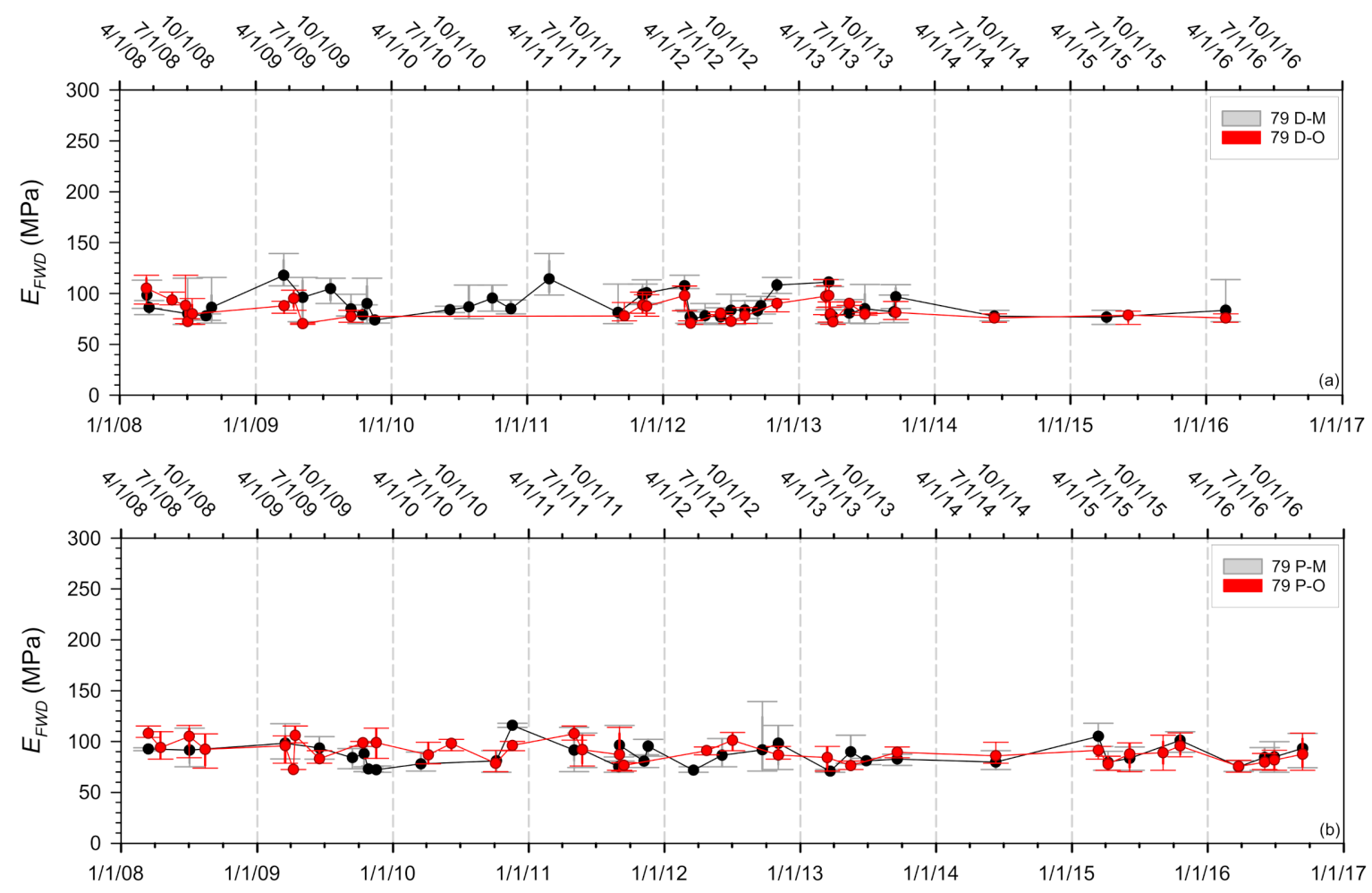

Figure 10. Seasonal variations in (a) driving lane $\mathrm{E}_{\mathrm{FWD}}$ and (b) passing lane $\mathrm{E}_{\mathrm{FWD}}$ of Cell 79 base- $50 \%$ RAP $+50 \% \mathrm{Class} 3$ stabilized with $14 \%$ fly ash (Section 7 ).

To summarize, the first key finding from the seasonal back-calculated layer modulus was that replacing natural aggregate base with $100 \%$ or $50 \%$ RCA improved the base layer stiffness from a long-term perspective. However, this replacement also brought a wider variation in the layer modulus in different seasons. Similarly, the layer modulus of pure RAP base ranged widely, especially in the measurements obtained from the outer wheel path. In addition, replacing natural aggregates with $100 \%$ RAP improved the long-term base performance, but the improvement was less than with RCA replacements. Even though the range of $\mathrm{E}_{\mathrm{FWD}}$ of the base consisting of $50 \% \mathrm{RAP}$ and $50 \%$ natural aggregates was smaller than the other recycled material sections, i.e., they stiffened less when freezing and weakened less when thawing, the $\mathrm{E}_{\mathrm{FWD}}$ was critically smaller than pure RAP or any RCA sections. The average $\mathrm{E}_{\mathrm{FWD}}$ of the $50 \% \mathrm{RAP}$ and $50 \%$ natural aggregates approximated the average value derived from the section with pure natural aggregate base, and both were around $100 \mathrm{MPa}$. It is implicit that recycled pavement materials may offer higher stiffness than natural aggregates when employed in pavement base constructions, but their capacity to resist seasonal temperature variations is likely not to be comparable to natural aggregates. Relatively lower fine content of recycled pavement materials may have contributed to this finding, since lower fine content indicates a higher void ratio, which allows more free water to freeze and thaw, resulting in greater changes in seasonal modulus values.

Moreover, it is difficult to make a comparison between the outer wheel-path and mid-lane data, especially for the passing lane measurements, because there was no traffic in that lane. From a long-term point of view, the driving lane and passing lane measurements did not considerably differ from each other, except for the 100\% RAP section. This finding implies that compared to long-term climatic loading, the impact of traffic loading on pavement base performance is negligible. 

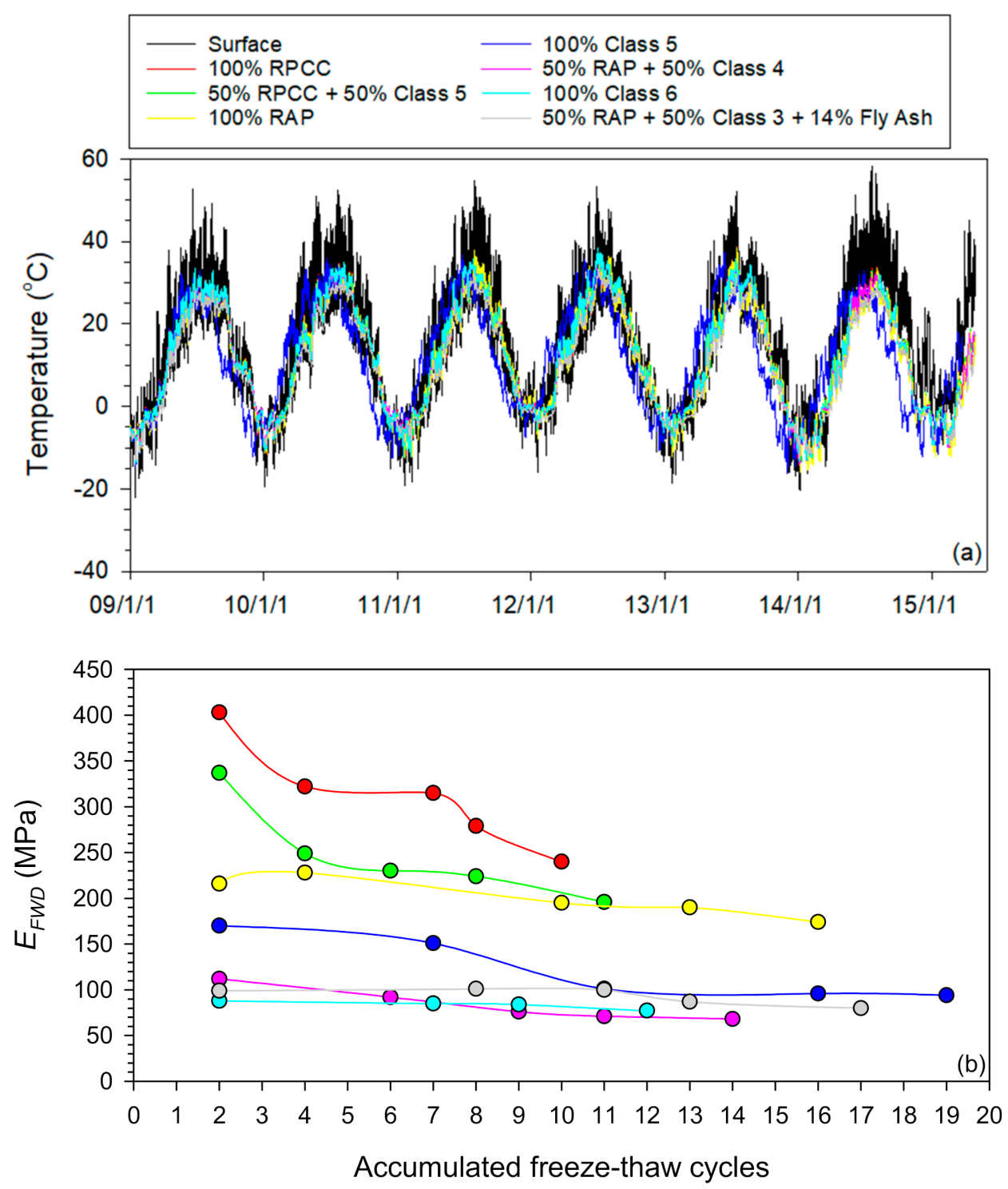

Figure 11. Plots of (a) temperature measurements representing the surface and base and (b) accumulated freeze-thaw cycles versus the representative $\mathrm{E}_{\mathrm{FWD}}$.

\section{Summary and Conclusions}

The use of recycled materials in pavement construction is a beneficial activity that reduces energy consumption and greenhouse gas emissions in material production associated with natural materials. Long-term performance of pavement base is usually impacted by seasonal climatic variations. In this study, falling weight deflectometer tests were conducted regularly over a long-term period to evaluate multiple types of aggregate base. Recycled pavement materials including recycled concrete aggregate (RCA) and reclaimed asphalt pavement (RAP), natural aggregates, and blended materials were used to construct test sections. Falling weight deflectometer tests were conducted twice yearly and the back-calculated elastic moduli of the base layers was assessed. Moreover, rutting and IRI data for test sections were recorded to monitor the pavement ride quality. Key findings derived from this study are listed as follows.

- In comparison with natural aggregate base, RCA and RAP improved the long-term performance of the base course. Replacing natural aggregates with 50\% and 100\% RCA and 100\% RAP explicitly elevated the overall base layer modulus. This indicates that recycled pavement material has a higher stiffness than natural aggregates. 
- The replacement of natural aggregates with recycled pavement materials led to wider seasonal variations in the base layer modulus. Different fine-content pavement base materials may result in different freeze-thaw resistance.

- Fly ash did not provide significant improvement in the long-term performance of $50 \%$ RAP plus 50\% natural aggregate base.

- From a long-term point of view, the impact of traffic loading on pavement base performance was negligible compared to climatic loading. In other words, seasonal variations turned out to affect pavement performance more critically than traffic loading.

- Even though the base layer mechanical properties were altered with the varying materials, the pavement ride quality in terms of IRI and rutting depth was not observed to be significantly different.

Author Contributions: Conceptualization, T.B.E., B.C. and Y.Z.; methodology, T.B.E. and B.C.; validation, Y.Z., B.C. and T.B.E.; formal analysis, Y.Z., T.B.E. and B.C.; investigation, Y.Z., T.B.E. and B.C.; resources, T.B.E. and B.C.; data curation, T.B.E. and B.C.; writing-original draft preparation, Y.Z. and B.C.; writing - review and editing, T.B.E. and B.C.; visualization, Y.Z.; supervision, B.C. and T.B.E.; project administration, T.B.E. and B.C.; funding acquisition, T.B.E. All authors have read and agreed to the published version of the manuscript.

Funding: This research was funded by the U.S. Federal Highway Administration (FHWA) through the TPF-5 (129) Recycled Unbound Materials Pool Fund administered by the Minnesota Department of Transportation (MnDOT) and the Recycled Materials Resource Center (RMRC).

Data Availability Statement: All data, models, and code that support the findings of this study are available from the corresponding author upon reasonable request.

Acknowledgments: These results are based on work supported by the TPF-5 (129) Recycled Unbound Materials Pool Fund administered by the Minnesota Department of Transportation and the Recycled Materials Resource Center (RMRC), which is supported by the U.S. Federal Highway Administration. The authors thank Ben Worel for his kind assistance in providing the field data.

Conflicts of Interest: No potential conflict of interest is reported by the authors. The opinions, findings, conclusions, and recommendations expressed herein are those of the author(s) and do not necessarily represent the views of the sponsors.

\section{References}

1. Robinson, G.R.; Menzie, W.; Hyun, H. Recycling of construction debris as aggregate in the Mid-Atlantic Region, USA. Resour. Conserv. Recycl. 2004, 42, 275-294. [CrossRef]

2. Rosa, M.G.; Cetin, B.; Edil, T.B.; Benson, C.H. Development of a Test Procedure for Freeze-Thaw Durability of Geomaterials Stabilized With Fly Ash. Geotech. Test. J. 2016, 39, 20150126. [CrossRef]

3. Tam, V.W.Y.; Butera, A.; Le, K.N. Recycled Aggregate in Concrete Production: A New Approach. In 21st International Symposium on Advancement of Construction Management and Real Estate; Springer Science and Business Media LLC: Berlin, Germany, 2017; pp. 1133-1139.

4. Disfani, M.; Arulrajah, A.; Bo, M.; Hankour, R. Recycled crushed glass in road work applications. Waste Manag. 2011, 31, 2341-2351. [CrossRef] [PubMed]

5. Singh, D.; Sawant, D.; Xiao, F. High and intermediate temperature performance evaluation of crumb rubber modified binders with RAP. Transp. Geotech. 2017, 10, 13-21. [CrossRef]

6. Arabani, M.; Nejad, F.M.; Azarhoosh, A. Laboratory evaluation of recycled waste concrete into asphalt mixtures. Int. J. Pavement Eng. 2013, 14, 531-539. [CrossRef]

7. Dang, L.C.; Fatahi, B.; Khabbaz, H. Behaviour of Expansive Soils Stabilized with Hydrated Lime and Bagasse Fibres. Procedia Eng. 2016, 143, 658-665. [CrossRef]

8. Chen, M.-Z.; Lin, J.-T.; Wu, S.-P.; Liu, C.-H. Utilization of recycled brick powder as alternative filler in asphalt mixture. Constr. Build. Mater. 2011, 25, 1532-1536. [CrossRef]

9. Ahmedzade, P.; Sengoz, B. Evaluation of steel slag coarse aggregate in hot mix asphalt concrete. J. Hazard. Mater. 2009, 165, 300-305. [CrossRef]

10. Fauzi, A.; Fauzi, U.J.; Nazmi, W.A.R.W.M. Engineering Quality Improvement of Kuantan Clay Subgrade using Recycling and Reused Materials as Stabilizer. Procedia Eng. 2013, 54, 675-689. [CrossRef] 
11. Smagulova, N.; Kairbekov, Z.; Ermek, A.; Yermoldina, E. Production of Bitumens from Coal Sources Modified by Elementary Sulfur. Adv. Mater. Res. 2012, 535-537, 1815-1818. [CrossRef]

12. Tasdemir, Y. High temperature properties of wax modified binders and asphalt mixtures. Constr. Build. Mater. 2009, 23, 3220-3224. [CrossRef]

13. Mashaan, N.S.; Chegenizadeh, A.; Nikraz, H.; Rezagholilou, A. Investigating the engineering properties of asphalt binder modified with waste plastic polymer. Ain Shams Eng. J. 2021, 12, 1569-1574. [CrossRef]

14. Costa, L.M.; Silva, H.M.; Peralta, J.; Oliveira, J.R. Using waste polymers as a reliable alternative for asphalt binder modification Performance and morphological assessment. Constr. Build. Mater. 2019, 198, 237-244. [CrossRef]

15. Cuadri, A.; Roman, C.; García-Morales, M.; Guisado, F.; Moreno, E.; Partal, P. Formulation and processing of recycled-lowdensity-polyethylene-modified bitumen emulsions for reduced-temperature asphalt technologies. Chem. Eng. Sci. 2016, 156, 197-205. [CrossRef]

16. Vila-Cortavitarte, M.; González, P.L.; Calzada-Perez, M.A.; Indacoechea-Vega, I. Analysis of the influence of using recycled polystyrene as a substitute for bitumen in the behaviour of asphalt concrete mixtures. J. Clean. Prod. 2018, 170, $1279-1287$. [CrossRef]

17. Mastic asphalt modified with recycled polyurethane foam. J. Croat. Assoc. Civ. Eng. 2018, 70, 403-412. [CrossRef]

18. Ahmedzade, P.; Demirelli, K.; Günay, T.; Biryan, F.; Alqudah, O. Effects of Waste Polypropylene Additive on the Properties of Bituminous Binder. Procedia Manuf. 2015, 2, 165-170. [CrossRef]

19. Hasan, M.R.M.; Colbert, B.; You, Z.; Jamshidi, A.; Heiden, P.A.; Hamzah, M.O. A simple treatment of electronic-waste plastics to produce asphalt binder additives with improved properties. Constr. Build. Mater. 2016, 110, 79-88. [CrossRef]

20. Ziari, H.; Nasiri, E.; Amini, A.; Ferdosian, O. The effect of EAF dust and waste PVC on moisture sensitivity, rutting resistance, and fatigue performance of asphalt binders and mixtures. Constr. Build. Mater. 2019, 203, 188-200. [CrossRef]

21. Milad, A.A.; Ali, A.S.B.; Yusoff, N.I.M. A Review of the Utilisation of Recycled Waste Material as an Alternative Modifier in Asphalt Mixtures. Civ. Eng. J. 2020, 6, 42-60. [CrossRef]

22. Arulrajah, A.; Baghban, H.; Narsilio, G.A.; Horpibulsuk, S.; Leong, M. Discrete element analysis of recycled concrete aggregate responses during repeated load triaxial testing. Transp. Geotech. 2020, 23, 100356. [CrossRef]

23. Fedrigo, W.; Núñez, W.P.; Visser, A.T. A review of full-depth reclamation of pavements with Portland cement: Brazil and abroad. Constr. Build. Mater. 2020, 262, 120540. [CrossRef]

24. Gonzalo-Orden, H.; Linares-Unamunzaga, A.; Pérez-Acebo, H.; Díaz-Minguela, J. Advances in the Study of the Behavior of Full-Depth Reclamation (FDR) with Cement. Appl. Sci. 2019, 9, 3055. [CrossRef]

25. Domitrović, J.; Rukavina, T.; Lenart, S. Effect of freeze-thaw cycles on the resilient moduli and permanent deformation of RAP/natural aggregate unbound base mixtures. Transp. Geotech. 2019, 18, 83-91. [CrossRef]

26. Edil, T.B.; Cetin, B.; Soleimanbeigi, A. Laboratory and field performance of recycled aggregate base in a seasonally cold region. Sci. Cold Arid. Reg. 2018, 9, 183-191.

27. Zhang, Y. Frost-Heave and Thaw-Weakening of Pavement Foundation Materials. Master's Thesis, Iowa State University, Ames, IA, USA, 2013. Available online: https:/ / lib.dr.iastate.edu/etd/13617 (accessed on 2 October 2021).

28. Becker, P.J.; White, D.J.; Vennapusa, P.K.R.; White, C.I.; Zhang, Y. Performance Comparison of Recycled Pavement Foundation Layers. Transp. Res. Rec. J. Transp. Res. Board 2015, 2509, 29-39. [CrossRef]

29. Lee, J.; Edil, T.B.; Benson, C.H.; Tinjum, J.M. Building Environmentally and Economically Sustainable Transportation Infrastructure: Green Highway Rating System. J. Constr. Eng. Manag. 2013, 139, A4013006. [CrossRef]

30. Ullah, S.; Tanyu, B.F. Methodology to develop design guidelines to construct unbound base course with reclaimed asphalt pavement (RAP). Constr. Build. Mater. 2019, 223, 463-476. [CrossRef]

31. Arshad, M. Laboratory investigations on the mechanical properties of cement treated RAP-natural aggregate blends used in base/subbase layers of pavements. Constr. Build. Mater. 2020, 254, 119234. [CrossRef]

32. Zhang, Y.; Johnson, A.E.; White, D.J. Freeze-thaw performance of cement and fly ash stabilized loess. Transp. Geotech. 2019, 21, 100279. [CrossRef]

33. Lee, W.; Bohra, N.; Altschaeffl, A.; White, T. Resilient modulus of cohesive soils and the effect of freeze-thaw. Can. Geotech. J. 1995, 32, 559-568. [CrossRef]

34. Cetin, B.; Aydilek, A.H.; Guney, Y. Stabilization of recycled base materials with high carbon fly ash. Resour. Conserv. Recycl. 2010, 54, 878-892. [CrossRef]

35. Li, C.; Ashlock, J.C.; Lin, S.; Vennapusa, P.K. In situ modulus reduction characteristics of stabilized pavement foundations by multichannel analysis of surface waves and falling weight deflectometer tests. Constr. Build. Mater. 2018, 188, 809-819. [CrossRef]

36. Zhang, Y.; Johnson, A.E.; White, D.J. Laboratory freeze-thaw assessment of cement, fly ash, and fiber stabilized pavement foundation materials. Cold Reg. Sci. Technol. 2016, 122, 50-57. [CrossRef]

37. NASA Earth Observatory, Published 11 December 2000. Available online: https:/ / earthobservatory.nasa.gov / (accessed on 2 October 2021).

38. Soleimanbeigi, A.; Shedivy, R.F.; Tinjum, J.M.; Edil, T.B. Climatic effect on resilient modulus of recycled unbound aggregates. Road Mater. Pavement Des. 2015, 16, 836-853. [CrossRef] 
39. Vuong, B.T. The use of finite element methods for verifying the choice of elastic layer models adopted in a back-analysis model for pavement overlay design. In Proceedings of the 6th International Conference on Finite Element Methods, Sydney, Australia, 8-10 July 1991; Available online: https:/ / trid.trb.org/view/1199570 (accessed on 2 October 2021).

40. AASHTO. Guide for Design of Pavement Structures; American Association of State Highway and Transportation Officials: Washington, DC, USA, 1993.

41. Liu, W.; Scullion, T. MODULUS 6.0 FOR WINDOWS: USER'S MANUAL; Texas Transportation Institute: College Station, TX, USA, 2001. Available online: https://apps.itd.idaho.gov/apps/manuals/Materials/Materials\%20References/Rep-1869-3b.pdf (accessed on 2 October 2021).

42. Fernando, E.G.; Liu, W.; Ryu, D. Development of A Procedure for Temperature Correction of Backcalculated AC Modulus; Report FHWA/TX-02/1863-1. Texas Transportation Institute, The Texas A\&M University System: College Station, TX, USA, 2001. Available online: https:/ / static.tti.tamu.edu/tti.tamu.edu/documents/1863-1.pdf (accessed on 2 October 2021).

43. Sigdel, P. Improving Design Strategies for Composite Pavement Overlay: Multi-layered Elastic Approach and Reliability Based Models. Ph.D. Thesis, The University of Toledo, Ohio, OH, USA, 2016. Available online: http://rave.ohiolink.edu/etdc/view? acc_num=toledo1480435567302893 (accessed on 2 October 2021).

44. Huang, Y. Pavement Analysis and Design; Pearson: Upper Saddle River, NJ, USA, 2004.

45. Sidess, A.; Ravina, A.; Oged, E. A model for predicting the deterioration of the international roughness index. Int. J. Pavement Eng. 2020, 1-11. [CrossRef]

46. Pérez-Acebo, H.; Gonzalo-Orden, H.; Findley, D.J.; Rojí, E. Modeling the international roughness index performance on semi-rigid pavements in single carriageway roads. Constr. Build. Mater. 2021, 272, 121665. [CrossRef]

47. Song, Y.; Wu, P.; Li, Q.; Liu, Y.; Karunaratne, L. Hybrid Nonlinear and Machine Learning Methods for Analyzing Factors Influencing the Performance of Large-Scale Transport Infrastructure. IEEE Trans. Intell. Transp. Syst. 2021, 1-14. [CrossRef] 